\title{
Staphylococcal protein A; its preparation and an application to rubella serology
}

\author{
H. MALlinson, C. ROBERTS, AND G. B. BRUCE WHITE \\ From the Regional Public Health Laboratory, Fazakerley Hospital, Liverpool
}

SYNOPSIS Good yields of staphylococcal protein A are obtained by growing the staphylococcus Cowan type 1 on cellophane agar. The activity of these preparations in removing immunoglobulin $\mathrm{G}$ (IgG) from human serum can be readily measured by the Mancini radial-diffusion technique and the correct in-use dilution determined. Treatment with protein A of sera from women with a history of rubella may help in the identification of those having specific antibody in the $\operatorname{IgM}$ and $\operatorname{IgA}$ fractions. This relatively simple procedure may have worthwhile application in the diagnosis of rubella.

In the serological diagnosis of recent rubella infection, problems arise when the antibody titre by haemagglutination-inhibition (HAI) or complementfixation (CF) tests has already reached a high level which does not show any significant change when paired sera are tested. In such cases the diagnosis of recent infection depends on the demonstration of rubella antibody in the IgM or IgA classes.

Ankerst et al (1974) showed that $95 \%$ of IgG could be removed from serum by absorption with staphylococccal protein A without significantly affecting the IgA, IgD or IgM content. The technical simplicity of the method may make it more suitable for immunoglobulin analysis than current methods such as sucrose density, gel-filtration or fluorescence techniques for the serological diagnosis of rubella.

We describe here a comparison of two methods for the production of protein $\mathrm{A}$ and its effect on the immunoglobulin content of sera from women with serological evidence of recent rubella infection.

\section{Material and methods}

\section{SERA}

The sera investigated were 33 samples from women in whom HAI and CF tests had indicated rubella infection within the previous 12 days to 20 weeks. A human reference serum for immunogloblin determinations was obtained from a healthy adult male and stored in aliquots at $-70^{\circ} \mathrm{C}$.
PROTEIN A

Preparation

Two methods were tested for the cultivation of Staphylococcus aureus Cowan 1 (NCTC 8530):

(a) in liquid medium, in $200 \mathrm{ml}$ volumes of casein casein yeast (CCY) broth (Arvidson et al, 1971) in $80 \mathrm{oz}$ Winchester bottles loosely plugged with cotton wool which, after inoculation with $10 \mathrm{ml}$ volumes of six-hour, log-phase, CCY broth cultures, were incubated at $37^{\circ} \mathrm{C}$ for 18 hours with rolling at 3 $\mathrm{rev} / \mathrm{min}$ to promote aeration;

(b) on solid medium, on CCY agar ( $2 \%$ Difco agar in CCY broth) in $150 \mathrm{ml}$ volumes in $23 \mathrm{~cm}$ square plastic dishes (NUNC-BIO assay plate no. 1015). This was overlaid with dialysis membrane (AutoAnalyzer type C, DHAAI Laboratory, Pharmaceutical and Industrial Services, Shipley, Yorkshire). The cellophane-covered agar was flooded with six-hour, log-phase broth culture and incubated at $37^{\circ} \mathrm{C}$ for 18 hours after removal of excess fluid. The cellophane was then removed in sections, which were transferred to $20 \mathrm{ml}$ aliquots of Dulbecco phosphate-buffered saline, $\mathrm{pH} 7 \cdot 3$ (PBS), and shaken to remove the staphylococci.

The staphylococcal cultures from method $(a)$ and suspensions from method (b) were centrifuged at $2500 \mathrm{rev} / \mathrm{min}$ for 45 minutes in an MSE Major centrifuge. Then using an MSE Mistral centrifuge (4000 rev/min for 10 minutes) the deposits were washed three times in PBS. The washed bacteria were treated for 3 hours at room temperature with $100 \mathrm{ml}$ of $0.5 \%$ formaldehyde in PBS, washed twice more with PBS, then, following the method of Kronvall (1973), heated briefly at $80^{\circ} \mathrm{C}$ and resuspended at a concentration of $10 \%$ (vol/vol) in PBS containing 
$0 \cdot 1 \%$ sodium azide. The stock $10 \%$ suspensions were stored at $4^{\circ} \mathrm{C}$ until used.

\section{Measurement of activity}

The affinity of each $10 \%$ staphylococcal suspension for IgA, IgM, and IgG was assayed by mixing $0.5 \mathrm{ml}$ of a reference serum diluted in PBS with the centrifuged deposits from $2.0 \mathrm{ml}$ volumes of serial twofold dilutions of the suspensions. The organisms were removed by centrifugation after standing for 30 minutes at room temperature. Tri-partigen and LCpartigen immunodiffusion plates (Hoechst) were used to determine the immunoglobulin levels of the original reference serum dilutions and the residual IgA, IgM, and IgG after their absorption. An initial 10-fold dilution of the reference serum was suitable for IgG estimations while a twofold dilution was used in the measurement of the $\operatorname{IgA}$ and $\operatorname{IgM}$.

\section{TESTS FOR RUBELLA ANTIBODY}

Preliminary treatment of sera

Before carrying out chick cell haemagglutinationinhibition tests it was necessary to remove from test sera non-specific agglutinins of chick erythrocytes and non-specific inhibitors of haemagglutination by rubella virus. This was achieved by adding $0.1 \mathrm{ml}$ of $1 \mathrm{M} \mathrm{MnCl}_{2}$ and $0.1 \mathrm{ml}$ of heparin solution (5000 units $/ \mathrm{ml}$ ) to 0.2 volumes of unheated serum samples diluted in $0.4 \mathrm{ml}$ dextrose gelatin veronal buffer (DGV).

After 30 minutes at $4{ }^{\circ} \mathrm{C} 0.05 \mathrm{ml}$ of a $50 \%$ suspension of chick erythrocytes was added; after a further one hour at $4^{\circ} \mathrm{C}$ the mixture was centrifuged at $2000 \mathrm{rev} / \mathrm{min}$ for 20 minutes to remove precipitated inhibitors and chick erythrocytes. The supernatant fluid was diluted with DGV to give a final 10 -fold dilution of the original serum.

\section{Absorption of sera by protein $A$}

Two-millilitre volumes of $10 \%$ staphylococcal suspensions were centrifuged in an angle head centrifuge in bijou bottles and the supernatant was removed. The sedimented staphylococci were resuspended in $0.5 \mathrm{ml}$ volumes of the 10-fold dilutions of treated test sera. After standing at room temperature for 30 minutes the mixtures were centrifuged to remove the staphylococci.

\section{Haemagglutination-inhibition tests}

$0.1 \mathrm{ml}$ of serial doubling dilutions of the pretreated serum were allowed to react with $0.1 \mathrm{ml}$ of rubella HA antigen (Burroughs Wellcome \& $\mathrm{Co}$ ) diluted in DGV to give four haemagglutinating doses either at room temperature for one hour (short incubation) or at $4^{\circ} \mathrm{C}$ for 18 hours (long incubation) before addition of $0.5 \%$ erythrocytes from one-day-old chicks.

\section{Results}

PRODUCTION OF PROTEIN A

Comparison of the two methods, in liquid or solid media, for the cultivation of Staphylococcus aureus showed that the $10 \%$ staphylococcal suspensions obtained were of about equal protein A activity (figure). However, cultivation on cellophane agar

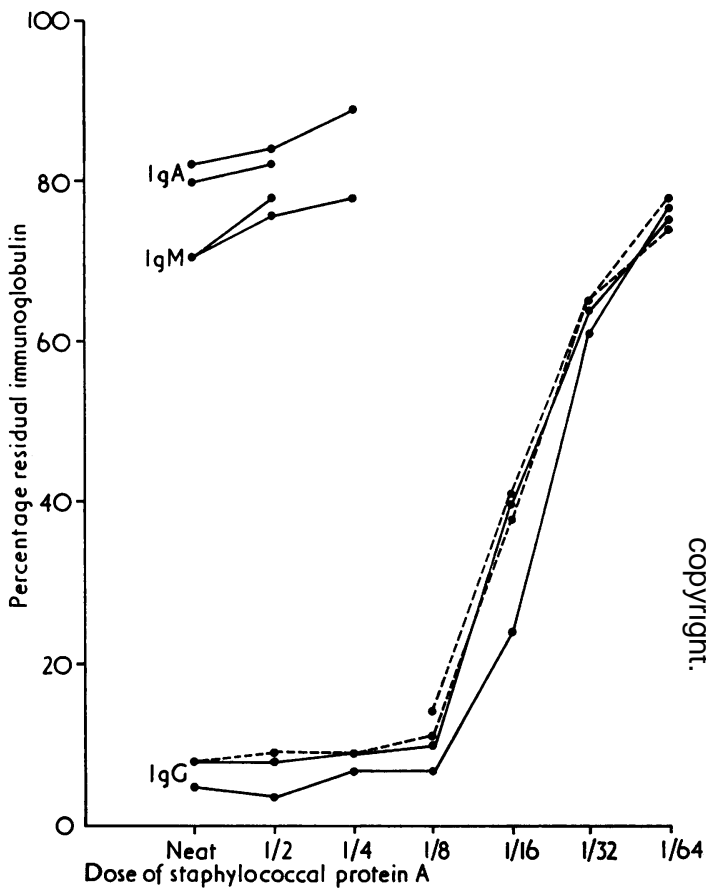

Figure Effecı on immunoglobulin levels of neat $(0.2 \mathrm{ml})$ and decreasing volumes of staphylococcal protein $A$ from agar (- $\longrightarrow$ ) and broth (- - - - cultures.

was the more convenient method because it involved less centrifugation and was more productive. Typical yields of the $10 \%$ staphylococcal suspensions used in these experiments were $150 \mathrm{ml}$ from $240 \mathrm{ml}$ of staphylococcal suspension harvested from 12 을 cellophane agar plates but only $25 \mathrm{ml}$ from $1260 \mathrm{ml} N$ of broth culture in six Winchester bottles.

\section{ABSORPTION OF IMMUNOGLOBULINS BY}

PROTEIN A

The absorption by protein A suspensions of $\operatorname{IgG}, \infty$ IgM, and IgA from a normal human reference serum (containing IgG $12.0 \mathrm{~g} / \mathrm{l}, \operatorname{IgM} 0.9 \mathrm{~g} / \mathrm{l}$, and IgA $1.5 \stackrel{\infty}{+}$ $\mathrm{g} / \mathrm{l})$ was determined by radial-diffusion tests before 0 and after treatment of the serum. The figure shows the proportion of IgG removed by various dilutions 
of stock suspensions obtained from either liquid or solid media. There is clearly little difference in this respect between the suspensions produced by the two methods. At dilutions of $1 / 32$ or $1 / 16$ they reduced the IgG level by about $50 \%$, at $1 / 8$ by more than $85 \%$, and at $1 / 4$ by more than $90 \%$. The one preparation that showed much less activity than this had been inadvertently held in PBS at $4{ }^{\circ} \mathrm{C}$ for two days before treatment with formaldehyde and heat. The effect on IgM and IgA levels of treatment of the serum with lower dilutions of suspensions prepared on solid media is also shown in the figure. Although there was a reduction in these levels it is clearly much less than that of IgG, and the loss of IgM and IgA tends to be reduced by decreasing the staphylococcal dose to which sera are exposed.

RUBELLA ANTIBODY LEVELS AFTER PROTEIN A ABSORPTION

Table I shows the rubella HAI titres (long incubation method) of 33 sera collected between 12 days and 20 weeks after the onset of rash; titres were determined before and after absorption with protein $\mathrm{A}$. The

\begin{tabular}{|c|c|c|c|}
\hline \multirow[t]{2}{*}{$\begin{array}{l}\text { Serum } \\
\text { no. }\end{array}$} & \multirow{2}{*}{$\begin{array}{l}\text { Days after } \\
\text { appearance of } \\
\text { rash }\end{array}$} & \multicolumn{2}{|c|}{$\begin{array}{l}\text { Rubella haemagglutination } \\
\text { inhibition titre }\end{array}$} \\
\hline & & $\begin{array}{l}\text { Serum not } \\
\text { absorbed }\end{array}$ & $\begin{array}{l}\text { Serum absorbed } \\
\text { with protein } A\end{array}$ \\
\hline 1 & 12 & 2560 & 120 \\
\hline 2 & 13 & 1280 & 20 \\
\hline 3 & 16 & 3840 & 160 \\
\hline 4 & 16 & $>5120$ & 320 \\
\hline 5 & 17 & 640 & 20 \\
\hline 6 & 17 & 640 & 30 \\
\hline 7 & 17 & 640 & 40 \\
\hline 8 & 17 & 1920 & 120 \\
\hline 9 & 18 & $>5120$ & 40 \\
\hline 10 & 18 & 2560 & 120 \\
\hline 11 & 19 & 2560 & 160 \\
\hline 12 & 21 & 1280 & 40 \\
\hline 13 & 21 & 1280 & 40 \\
\hline 14 & 23 & 2560 & 40 \\
\hline 15 & 24 & 2560 & 80 \\
\hline 16 & 24 & 640 & 20 \\
\hline 17 & 27 & 1280 & 20 \\
\hline 18 & 27 & 1280 & $<10$ \\
\hline 19 & 30 & 1280 & 10 \\
\hline 20 & 32 & 2560 & 40 \\
\hline 21 & 35 & 640 & $<10$ \\
\hline 22 & 42 & 2560 & 40 \\
\hline 23 & 42 & 1920 & 10 \\
\hline 24 & 42 & $>5120$ & 10 \\
\hline 25 & 47 & 1280 & 10 \\
\hline 26 & 49 & 640 & $<10$ \\
\hline 27 & 49 & 1280 & 10 \\
\hline 28 & 49 & 320 & $<10$ \\
\hline 29 & 52 & 1920 & $<10$ \\
\hline 30 & 70 & 2560 & $<10$ \\
\hline 31 & 77 & 480 & $<10$ \\
\hline 32 & 84 & 1920 & 10 \\
\hline 33 & 140 & 960 & $<10$ \\
\hline
\end{tabular}

Table I Effect of staphylococcal protein $A$ absorption on HAI titres of sera collected 12 to 140 days after rubella rash earliest serum sample in which there was no detectable HAI activity after absorption with protein $\mathbf{A}$ was collected on day 27. Sera collected earlier than that had post-absorption titres in the range 20 to 320 . Among sera collected before day 27 none had a postabsorption titre of less than 20, and among those collected after day 42 none had a post-absorption titre of more than 10.

\section{FACTORS AFFECTING THE TEST FOR}

RUBELLA ANTIBODY

Sensitivity of the HAI test

With the 'long incubation' test 12 of 14 sera gave titres that were more than twofold greater than when the 'short incubation' method was used. This difference in sensitivity was important in the case of one serum collected 17 days after onset of rash which had a post-absorption titre of less than 10 by the 'short incubation' method but a titre of 20 after 'long incubation'.

\section{Dose of protein $A$}

The adequacy of the selected dose of protein A was investigated by measuring the residual HAI titre of serum no. 4 (table I) after two consecutive absorption treatments. This was the serum with the highest post-absorption titre (320) in our series but it remained unchanged after the second treatment.

\section{Ig $G$ content of sera}

To investigate the effect of individual variation in the level of total serum IgG on the residual HAI titre after protein A absorption, nine sera with high HAI titres were examined (table II). It is noteworthy that three of the four sera with the highest total IgG levels had residual HAI titres of less than 10.

\begin{tabular}{lll}
\hline Serum no. & $\begin{array}{l}\text { Total serum IgG } \\
(\mathrm{g} / \mathrm{l})\end{array}$ & $\begin{array}{l}\text { Post-absorption } \mathrm{HAI} \\
\text { titre }\end{array}$ \\
\hline 18 & $20 \cdot 6$ & $<10$ \\
29 & $15 \cdot 8$ & $<10$ \\
33 & $12 \cdot 8$ & $<10$ \\
27 & $12 \cdot 8$ & 10 \\
24 & 12.0 & 10 \\
17 & 10.6 & 20 \\
32 & 10.4 & 10 \\
30 & $9 \cdot 5$ & $<10$ \\
25 & 8.6 & 10 \\
\hline
\end{tabular}

Table II Comparison of total serum IgG levels with rubella $H A I$ titres after staphylococcal protein $A$ absorption

${ }^{1}$ Normal range 6-16 g/l

\section{Discussion}

Staphylococcus aureus Cowan 1 grown on dialysis membrane spread on the surface of casein casein 
yeast agar gave a high yield of protein $\mathrm{A}$ with IgG-absorbing activity at least equal to that of staphylococci grown in liquid cultures. Growth of staphylococci on a solid medium in this way provides diagnostic laboratories with a readily available source of protein A. The activity of these protein A preparations in absorbing IgG and the correct dose for use in serological tests can be assessed by determining IgA, IgG, and IgM by radial-diffusion techniques on sera before and after treatment. The reported day-to-day variations in protein A production by Cowan 1 and other strains of staphylococci (Kronvall et al, 1971) indicates the need for routine monitoring of the potency of protein A batches. Being technically simple and also commercially available, the Mancini technique offers advantages over the radioisotope method described by Ankerst et al (1974).

In relation to rubella serology, the value of the protein $\mathrm{A}$ absorption technique lies in the demonstration of residual IgM and IgA antibody indicative of recent infection after removal of most of the IgG. In this investigation we have demonstrated the importance of using the 'long incubation' haemagglutination-inhibition test which is more sensitive than the 'short incubation' method and more likely therefore to detect low titres of IgM antibody after absorption. There is some reduction in IgM and IgA titres after absorption with protein $\mathrm{A}$, greater in our hands (IgM $29 \%, \operatorname{IgA~} 19 \%$ ) than that reported by Ankerst et al (1974) (IgM 2.5\%, IgA 4\%). The reason for this difference is not clear but might be related to the use of myeloma protein by Ankerst $e t$ $a l$ or to the presence in our reference serum of antistaphylococcal IgM or IgA, although we have not investigated this. We have shown, however (figure), that loss of IgM and IgA may be reduced by careful adjustment of the dose of protein $A$.

Our results suggest that protein $\mathbf{A}$ absorption is effective in reducing rubella IgG antibody to a level less than the initial dilution, 1 in 10, used in the HAI test. In our series (table I), eight sera with initial titres in the range 320 to 2560 were all reduced to less than 10 after absorption. Although protein A combines with about $95 \%$ of serum IgG, it has no effect on subclass 3 , which represents about $5 \%$ of the total. The role of subclass 3 could be significant in relation to the effect of protein $\mathrm{A}$ in any serum with an initial titre of 200 or more in which a $95 \%$ 음 reduction might leave antibody detectable at the initial (1 in 10) dilution of the HAI test. Our findings $\stackrel{+}{+}$ evidently support the suggestion of Ankerst et al 을 (1974) that IgG of subclass 3 does not affect antibody titres determined by the rubella HAI test.

Using the protein A absorption technique, $\stackrel{\triangleright}{\unrhd}$ Ankerst et al (1974) were able to demonstrate residual post-absorption HAI activity in sera col- $\vec{\circ}$ lected between 7 and 14 days after the onset of rubella. We have extended the survey period to $\vec{\omega}$ between 12 days and 20 weeks after onset. Our $\stackrel{?}{?}$ findings (table I) show that it may be possible, by demonstrating residual post-absorption HAI activity, तु to diagnose recent rubella even when serum is first obtained 14 days or more after the onset of the rash, $\overrightarrow{0}$ by which time the HAI and CF titres have already 8 risen. Current investigations on a direct comparison with the sucrose density gradient technique may help to define the diagnostic precision of the protein $\mathrm{A}_{\bar{Z}}$ absorption method. However, the results presented here already indicate that the test is of value since it $\stackrel{\$}{\square}$ enables us to diagnose recent rubella in a number of patients without resorting to the more complex immunological methods.

We are indebted to our clinical colleagues providing the sera from their patients, to Dr Stott for the immunological assays, and to Dr G. C Turner for help in preparing the manuscript. We are grateful to Mrs Angela Simmons for secretarial help.

References

Ankerst, J., Christensen, P., Kjellén, L., and Kronvall, G. (1974). A routine diagnostic test for IgA and IgM antibodies to rubella virus: absorption of IgG with Staphylococcus aureus. J. infect. Dis., 130, 268-273.

Arvidson, S., Holme, T., and Wadström, T. (1971). Influence $\frac{9}{0}$ of cultivation conditions on the production of extracellular proteins by Staphylococcus aureus. Acta. path. microbiol. scand. 79B, 399-405.

Kronvall, G. (1973). A rapid slide-agglutination method for $\frac{0}{3}$ typing pneumococci by means of specific antibody adsorbed to protein A-containing staphylococci. J. med. Microbiol., 음 6, 187-190.

Kronvall, G., Dossett, J. D., Quie, P. G., and Williams, R. C., Jr. (1971). Occurrence of protein A in staphylococcal strains: Quantitative aspects and correlation to antigenic $N$ and bacteriophage types. Infect. and Immun., 3, 10-15. 